\title{
APPLICATION OF SOME TYPES OF SEAWEEDS ON THE GROWTH AND YIELD OF SHALLOT (Allium ascalonicum L.)
}

\author{
Ramal Yusuf ${ }^{(1)}$, Abdul Syakur ${ }^{1)}$, Budiatno $^{2)}$, Hidayati Mas'ud ${ }^{3)}$ \\ ${ }^{1)}$ Lecturer at Program Study Agroteknologi Faculty of Agriculture University of Tadulako, Palu \\ ${ }^{2}$ Student at Program StudyAgroteknologi Faculty of Agriculture University of Tadulako, Palu \\ ${ }^{3)}$ School of Environmental and Rural Sciences University of New England Armidale, NSW 2351, Australia
}

\begin{abstract}
Shallot plant is often used as a flavor enhancer and appetite enhancer food. Research on shallotcrop has been done. Application of seaweedsgive a different effect on increasing the productivity and growth of shallots. This study aims to determine the effect of applying different types of seaweed on growth and yield of shallot variety Lembah Palu. This research was conducted at the Green House of Faculty of Agriculture, University of Tadulako from March to May 2016. The study conducted using a randomized block design (RBD). The treatments: $\mathrm{B}_{0}=$ control, $\mathrm{B}_{1}=$ NPK $0.2 \mathrm{~g} /$ pot, $\mathrm{B}_{2}=($ Cauelerpa $\mathrm{sp}) 100 \mathrm{ml} / \mathrm{pot}, \mathrm{B}_{3}=($ Sargassum $\mathrm{sp}) 100 \mathrm{ml} / \mathrm{pot}, \mathrm{B}_{4}=($ Eucheuma cottonii) $100 \mathrm{ml} /$ pot, $\mathrm{B}_{5}=$ Sea lettuce (Ulva sp) $100 \mathrm{ml} /$ pot. there are six treatments, each treatment was replicated four times, so there are 24 experimental units. The results indicatedthat the application of various types of seaweed significant effect on plant height, fresh weight of the plants, the fresh weight of tuber and diameter of the bulb.
\end{abstract}

Key Words : Growth, seaweed, shallot.

\section{INTRODUCTION}

Shallot is a vegetable plant is often used by the people of Indonesia. Almost every area uses shallot on each dish that serves as a flavor enhancer and appetite enhancer food with rich aroma. Besides that shallots can also be used as a home-based business industry as an additional income of the community and local economy.

In the province of Central Sulawesi, especially in Palu, shallot can befoundthat are superior in local commodity area which is well known as a source of raw materials fried shallots and known to be very distinctive compared to among shallots in Indonesia. The type of local palu shallot is currently cultivated in the valley of Palu but the production is still low. In particular there are two types of shallots in local Palu and people of Central Sulawesi (tribal kaili) gives its name to the first type is the shallot "papaya" or shallots "tasima" and the second one is the shallot "rock" or "tatua". Thisis shallot with bulbs whitish when compared to other types of shallots in Indonesia. The type of shallot local Palu is excellent as a raw material of fried shallots with a distinctive aroma, texture dense, savory taste and hold it in storage after being fried (Department of Agriculture Central Sulawesi, 2012).

There are some reasons for low production of shallot variety lembah palu such as cultivation technology is not optimal, do not use organic fertilizers and the use abundant of inorganic fertilizers which can continuously reduce soil productivity due to decreased physical properties and soil fertility. Farmers generally provide manure to shallot just depends on the type and amount of manure available so that it may not correspond with the needs of the plant (Latarang and Syakur, 2006). The addition of seaweed containing organic matter and plant growth regulatorcan help the growth and increase the yield. Limbongan and Monde (1999) suggests 
that organic fertilizers 1.2 tone/ha produced the highest dry tubers (5.64 tone/ha) and significantly different compared with the tuber yield of the plots that were not given organic fertilizer.

Indonesia is one of the seaweed producer, however the use of seaweed in the country is still limited as a food product, product of semi-finished, as well as some cosmetic products, while the use of seaweed in agriculture and horticulture are still low. In other countries in the world, the application of seaweed for agricultural crops has been done, such as various types or forms of preparation seaweed include liquid seaweed fertilizer (LSF), seaweed liquid fertilizer (SLF), liquid fertilizer (LF), and chopped powdered algal manure are common on the market (Sedayu et al., 2013). Seaweed is also known as algae (seaweed) is the biggest part of the marine plants, which grow and thrive in almost all the waters of Indonesia, and is one of the marine and fishery commodities which have been used since a long time as an export commodity (Winarno, 1990). This plant is an important economic value because their use is very extensive, as groceries, organic fertilizer industry, cosmetics industry, textile industry and pharmaceutical industry. Utilization of seaweed such a magnitude resulting in seaweed contained various chemicals and other organic materials as well as vitamins (Hidayat, 1994).

Research on the shallot has been carried out. Nevertheless, the results of these studies can not be generalized to all areas as each location has their own character such as environments and applications. The aim of this research is to know the effect of seaweed on the growth and yield of shallot Lembah Palu variety.

\section{RESEARCH METHODS}

This research was conducted at the Green House of Faculty of Agriculture, University Tadulako March to May 2016.
The tools used in this study is a sieve, pot $(14 \mathrm{~cm} \times 18 \mathrm{~cm})$, cameras, scales, analytical balance, ruler, cutter, oven, and stationery. The materials used in this study is the seed shallot variety Lembah Palu (each pot 1 bulb). The soil taken from the village Lolu District Sigi (2 kg/pot),NPK fertilizer, and seaweeds. This research is compiled using a randomized block design (RBD) consisted of 6 treatments. The details are as follows:

B0 $=($ control/without seaweed $)$.

$\mathrm{B} 1=\mathrm{NPK} 0.2 \mathrm{~g} /$ pot.

B2 $=$ Seaweed of (Cauelerpa $\mathrm{sp}) 100 \mathrm{ml} /$ pot.

B3 = Seaweedof (Sargassum sp) $100 \mathrm{ml} /$ pot.

B4 = Seaweed of (Euchema cottonii) $100 \mathrm{ml} /$ pot.

B5 = Seaweed of (Ulva sp) $100 \mathrm{ml} /$ pot.

There are six treatments, each treatment was replicated four times, so there are 24 unit experimental. Data were analyzed using analysis of variance ( $F$ test $5 \%$ ), if treatments shown significantly then using test honestly significant difference (HSD) for further analyzes.

\section{RESULTS AND DISCUSSIOS}

\section{Results.}

Plant Height. The test results HSD 5\% (Table 1) shows that (ulva sp) produces the highest score is 17.20 and in contrast to the control, NPK, Caulerpa sp, Sargassum and Eucheuma cottonii, at the age of 6 weeks after planting. Whereas at the age of 8 and 10 MST (Eucheuma cottonii) gave the highest yield is 20.80 and 21.75 different from other treatments.

Fresh Bulbs Weight. Results HSD 5\% (Table 2) show that (ulva sp) gave the highest yield is 4.82 followed BY seaweed (Eucheuma cottonii) $4.56 \mathrm{~g}$ different from other treatments.

Bulb Dry Weight. Results HSD 5\% (Table 3) shows that the (Ulva sp) and (Eucheuma cottonii) provide the highest bulb dry weight $(1.13 \mathrm{~g})$ were different from NPK and Control treatments. 
Table 1. Plant height $(\mathrm{cm})$ age 6, 7, 8, 9, 10 WAP (Week After Planting)

\begin{tabular}{lccccc}
\hline \multirow{2}{*}{ Treatments } & \multicolumn{5}{c}{ Plant Age } \\
\cline { 2 - 6 } & $6 \mathrm{WAP}$ & $7 \mathrm{WAP}$ & $8 \mathrm{WAP}$ & $9 \mathrm{WAP}$ & $10 \mathrm{WAP}$ \\
\hline B0 = Control & $16,55^{\mathrm{b}}$ & $16,88^{\mathrm{b}}$ & $17,38^{\mathrm{ab}}$ & $17,50^{\mathrm{ab}}$ & $17,70^{\mathrm{a}}$ \\
$\mathrm{B} 1=$ NPK & $12,48^{\mathrm{a}}$ & $12,58^{\mathrm{a}}$ & $14,58^{\mathrm{a}}$ & $15,13^{\mathrm{a}}$ & $15,50^{\mathrm{a}}$ \\
$\mathrm{B} 2=$ Caulerpa sp & $13,75^{\mathrm{a}}$ & $17,35^{\mathrm{b}}$ & $17,58^{\mathrm{b}}$ & $18,18^{\mathrm{ab}}$ & $18,50^{\mathrm{b}}$ \\
$\mathrm{B} 3=$ Sargassum $\mathrm{sp}$ & $16,20^{\mathrm{b}}$ & $17,25^{\mathrm{b}}$ & $18,63^{\mathrm{bc}}$ & $18,20^{\mathrm{ab}}$ & $19,43^{\mathrm{bc}}$ \\
B4 = E. Cottonii & $16,90^{\mathrm{b}}$ & $18,73^{\mathrm{b}}$ & $20,80^{\mathrm{c}}$ & $21,10^{\mathrm{b}}$ & $21,75^{\mathrm{c}}$ \\
B5 = Ulva $\mathrm{sp}$ & $17,20^{\mathrm{b}}$ & $18,85^{\mathrm{b}}$ & $20,55^{\mathrm{c}}$ & $21,50^{\mathrm{b}}$ & $21,65^{\mathrm{c}}$ \\
\hline \multicolumn{1}{c}{ BNJ 5\% } & 1,82 & 2,03 & 2,90 & 4,16 & 2,57 \\
\hline
\end{tabular}

Description: Average Followed by The Same Letter in The Same Column do not Differ in The Level of 5\% HSD Test.

Table 2. Weight Fresh Bulb (g)

\begin{tabular}{lc}
\hline \multicolumn{1}{c}{ Treatments } & Bulb Fresh Weiht \\
\hline $\mathrm{B} 0=$ control & $2.06^{\mathrm{ab}}$ \\
$\mathrm{B} 1=$ NPK & $1.94^{\mathrm{a}}$ \\
$\mathrm{B} 2=$ Caulerpa $\mathrm{sp}$ & $3.62^{\mathrm{b}}$ \\
$\mathrm{B} 3=$ Sargassum sp & $3.17^{\mathrm{bc}}$ \\
$\mathrm{B} 4=$ Eucheuma cottonii & $4.56^{\mathrm{c}}$ \\
$\mathrm{B} 5=$ Ulva sp & $4.82^{\mathrm{c}}$ \\
\hline \multicolumn{1}{c}{ BNJ 5\% } & $1.22^{2}$ \\
\hline
\end{tabular}

Description: Average Fresh Bulb Weight Followed by The Same Letter in The Same Column do not Differ in the Level of 5\% HSD Test.

Table 3. Average Bulb Dry Weight (g)

\begin{tabular}{lc}
\hline \multicolumn{1}{c}{ Treatments } & Bulb Dry Weight \\
\hline B0 $=$ Control & $0.51^{\mathrm{a}}$ \\
$\mathrm{B} 1=$ NPK & $0.56^{\mathrm{a}}$ \\
$\mathrm{B} 2=$ Caulerpa $\mathrm{sp}$ & $0.83^{\mathrm{ab}}$ \\
$\mathrm{B} 3=$ Sargassum $\mathrm{sp}$ & $0,79^{\mathrm{ab}}$ \\
$\mathrm{B} 4=$ Eucheuma cottonii & $1.13^{\mathrm{b}}$ \\
$\mathrm{B} 5=$ Ulva sp & $1.13^{\mathrm{b}}$ \\
\hline \multicolumn{1}{c}{ BNJ 5\% } & 0.36
\end{tabular}

Description: Average Bulb Dry Weight Followed by The Same Letter in The Same Column do not Differ in The Level of 5\% HSD Test.

Table 4. Average Diameter of The Bulbs

\begin{tabular}{lc}
\hline \multicolumn{1}{c}{ Treatments } & Bulb Diameter \\
\hline $\mathrm{B} 0=$ Control & $0.82^{\mathrm{a}}$ \\
$\mathrm{B} 1=$ NPK & $0.80^{\mathrm{a}}$ \\
$\mathrm{B} 2=$ Caulerpa $\mathrm{sp}$ & $1.08^{\mathrm{b}}$ \\
$\mathrm{B} 3=$ Sargassum & $1.13^{\mathrm{b}}$ \\
$\mathrm{B} 4=$ Eucheuma cottonii & $1.18^{\mathrm{b}}$ \\
$\mathrm{B} 5=$ Ulva sp & $1.09^{\mathrm{b}}$ \\
\hline \multicolumn{1}{c}{ BNJ 5\% } & 0.19 \\
\hline
\end{tabular}

Description: Average of Bulb Diameter Followed by The Same Letter in The Same Column do not Differ in The Level of $5 \%$ HSD Test.
Bulbs Diameter. The test results HSD 5\% (Table 4) shows that the application of (Eucheuma cottonii) gave the highest yield, ie 1.18 and different from NPK treatment and control.

\section{Discussion.}

Based on the 0.05 HSD test (Tables 1) show that the parameters of plant high indicated seaweed of (Eucheuma cottonii) produces the highest value compared to seaweed of (Ulva sp), but the fresh bulb weight measurement shown that seaweed of (Ulva sp) higher than other types of seaweeds. The results of bioassay analysis on seaweed showed the present of hormones in those seaweed may boost the grownof plants (Yusufet al, 2012). The compounds on seaweed are known to play a role in plant growth. Compounds such as auxin plays a role in plant physiological processes, such as growth, division, and differentiation of cells, and protein synthesis. Gibberellins are known to influence the peak dormancy, growth cambium, geotropisme, abscission and Parthenocarpy, effectively increasing the fruit cells, stimulation of growth between the stem so that the plant does not dwarf (Gardner et al., 1991). While cytokinin play an important role in cell division that causes the response of plants to plant growth, fruit growth and germination of sprouts (Wu $\&$ Lin, 2000). This shows the observation plant high applied with seaweed of (Eucheuma cottonii) better than other treatment. According to Crouch \& van Staden (1992) 
the concentration of gibberellins contained in commercial organic fertilizers are made from seaweed such asMaxicrop amounting to 0.03 to $18.4 \mathrm{ppm}$, Kelpar 66 is 0.05 ppm, and Seaweed Extract of 53.6 to 149 ppm. Williams et al. (1976) stated that the low content of gibberellin on commercial organic fertilizer products can be caused by degradation of the compound at the time of processing/production, and also differences in the amount of content giberelin depending on the process used in commercial production. Differences content of cytokinins in seaweed extract is influenced by several factors, among them by seasonal factors, the development phase of seaweed (Mooney \& van Staden, 1984b), and the method of detection (Brenner, 1981) .In addition, the type of seaweed also affect the presence of cytokines in liquid extract of seaweed. This is also reinforced by studies Lin et al. (1996) that the content of cytokinins on some kind of green algae are Ulva pertusa, Enteromopha compressa, and Monostroma sp. which ranged from 0.02 to $0.045 \mathrm{ppm}$. This number is much lower compared to the results obtained from the extract Eucheuma cottonii.

HSD test result of 0.05 (Table 2) showed that the highest bulb fresh weight of the plant was obtained on seaweed of (Ulva sp) i.e 4.82. It showed that the higher the value of the bulb fresh weight of the plants produced better plant growt. The use of seaweed extract as a source of organic matter and nutrients, have been done long ago, known as soil moisture (soil conditioner) (Blunden, 1991). Many products made from seaweed, has been used as additional nutrients and as biostimulan or organic fertilizer (biofertilizer) to improve the growth and yield (Wajahatullah et al., 2009). This suggests that the growth of the plant is determined by factors other than genetic of every variety, is also influenced by environmental factors.

An increase in the metabolic processes of shallot plants causes the increased formation of carbohydrates, protein and fat in the end yield potential can be further increased. Auxin is a substance that encourages growth elongation and enlargement of cells, so that auxin also affect weight gain fresh.

HSD test result of 0.05 (Table 3) shows that the highest dry weight of the bulbsfound in seaweed of (Ulva sp) and (Eucheuma cottonii) is 1.13. This shows that the application of seaweed sea lettuce (Ulva sp) and (Eucheuma cottonii) at the appropriate concentration as a result increase the dry weight of tuber. The more leaves produced by the shallot the more the tubers produced by the shallots. According to Mukhlis (2011) number of leaves formed mean leaf area becomes wider, the ability of the leaves in the light for photosynthesis becomes larger in producing carbohydrates and will be translocated to tuber thus affecting the large and heavy of bulbs. Furthermore, according to Aryanti (2012) explains that the auxin increase the content of organic and inorganic substances in the cells. These substances are converted into proteins, nucleic acids, polysaccharides, and other complex molecules. The compound will form tissues and organs, so that the weight of the wet and dry weight of plants increased. Auxin could also increase the osmotic pressure of plants that increase the absorption of water by plants. Auxin will soften the cell walls resulting in increase water uptake by the cell.

HSD test result of 0.05 (Table 4) showed that the highest diameter of the bulbs found in applications of seaweed (Eucheuma cottonii) is 1.18. This is due to there are various factors that can influence the response of plant. These factors include the type and life cycle of the plant, growth stage or age of the plant, the availability of nutrients in the media, especially mineral status and climate. Kumar et. al (2007) stated that the management of water and nutrients during the production of shallot has ainfluence on the behavior of postharvest commodities. For example, shallots are grown in conditions of low soil moisture produces tubers that are smaller and tend to lose a lot of water so that the tubers dry 
faster during the storage. The results of this study proved that the role of seaweed in regulating the humidity medium capable of supporting the growth of shallot bulbs in particular diameter which increase the diameter of the bulb is in line with the application of seaweed (Eucheuma Cottonii). Seaweeds have good prospects for organic fertilizer because of its nutrient and particularly growth regulators. Plant growth regulators which contains among other auxin, cytokinin, and giberilin (Yusuf et al, 2015). PGR can not only increase production, but also increases plant resistance to drought and insect attack, as well as improve the soil structure (Basmal, 2009).

\section{CONCLUSIONS AND SUGGESTION}

\section{Conclusion.}

The conclusion of this research is the application of various types of seaweed significant effect on plant height, fresh bulb weight, dry weight of tuber and bulb diameter.

\section{Suggestion.}

Based on the research, it is suggested that need to do more research on the application of various types of nutrients seaweed in field.

\section{REFERENCES}

Aryanti, W. S. 2012. Kinerja Zat Pemacu Pertumbuhan dari Cairan Rumput Laut Sargassum Polycistum dalam Meningkatkan Pertumbuhan Kedelai (Glycine Max L Merril). Anatomi Fisiologi. 17(2): 41-47.

BPS, 2014. Sulawesi Tengah Dalam Angka 2014. Biro Statistik Prov. Sulawesi Tengah, Palu.

Brenner, M.I. 1981.Modern Methods for Plant Growth Substances Analysis. Ann. Rev. Plant. Physiol. 32: 511-538.

Basmal, J. 2009. Prospek Pemanfaatan Rumput Laut Sebagai Bahan Pupuk Organik. http://bbrp2b.kkp.go.id. Diakses pada tanggal 10 Januari 2016.

Blunden, G. 1991. Agricultural Uses of Seaweeds Ada Seaweed Extracts. In: Guiry, M.D, Blunden, G (eds). Seaweed Resources in Europe: Uses and Potential. Wiley, Chicester, pp 65-81

Crouch, I. J. and V, Staden. 1992. Identification Of Auxins in A Commercial Seaweed Concentrate. J. Plant Physiol.139: 590-594.

Dinas Pertanian, 2012. Data Luas Tanam, Luas Panen, Produksi dan Produktivitas Bawang Merah. Dinas Pertanian Prov. Sulawesi Tengah, Palu

Gardner, FP., R.B. Pearchdan. R.L, Mitchell. 1991. Fisiologi Tanaman terjemah oleh Herawati Susilo dan Subiyanto. 1991. Jakarta: Penerbit Universitas Indonesia. Hal.247-275.

Ghufran M, K, Kordi, 2010. Budidaya Biota Akuatik untuk Pangan, Kosmestik, dan Obat-obatan, Lily Publisher, Yogyakarta.

Hidayat, A., 1994, Budidaya Rumput Laut, Penerbit Usaha Nasimal, Surabaya.

Lin, D.D., P.,Li, Feng, S., Shun, Z.J., Tong, L.X., and F.X, Geng. 1996. Identification Cytokinin in A Green Algae Extract. Chin. J. Oceanol. Limnol. 12(2): 160-164.

Latarang B, A, Syakur, 2006. Pertumbuhan dan Hasil Bawang Merah (Allium ascalonicum L.) Pada Berbagai Dosis Pupuk Kandang. J. Agroland 13 (3) : 265 - 269.

Limbongan, J. dan A. Monde. 1999. Pengaruh Penggunaan Pupuk Organic dan Anorganik Terhadap Pertumbuhan dan Produksi Bawang Merah Kultivar Palu. J. Hortikultura 9(3): 212-219.

Limbongan, J. dan Maskar. 2003. Potensi Pengembangan dan Ketersediaan Teknologi Bawang Merah Palu di Sulawesi Tengah. J. LitbangPertanian 22 (3): 103108.

Mukhlis, P., dan D, Anggorowati, 2011.Pengaruh Berbagai Jenis Mikro orgasnime Lokal (Mol) Terhadap Pertumbuhan dan Hasil Bawang Merah pada Tanah Aluvial. Fakultas Pertanian Universitas Tanjungpura Pontianak. 
Suparmi, A, Sahri. 2009. Mengenal Potensi Rumput Laut. Kajian Pemanfaatan Sumber Daya Rumput Laut dari Aspek Industri dan Kesehatan. Sultan Agung, Vol. XLIV NO. 118.

Sedayu, B.B., J, Basmal,\& B.S.B, Utomo. (2013). Identifikasi Hormone Pemacu Tumbuh Ekstrak Cairan (Sap) Eucheuma Cottonii. J. Pasca panen dan Bioteknologi Kelautan dan Perikanan. 8(1): 1-8..

Ufiyani, 2003. Pengaruh Panjang Stek dan Konsentrasi Zat Pengatur Tumbuh BAP Terhadap Rejuvenasi Stek Cabang Kayu Putih (Melaleuca cajuputi). Skripsi, Fakultas Pertanian Universitas Tadulako. Palu.

Winarno, F.G., 1990, Teknologi Pengolahan Rumput Laut. Pustaka Sinar Harapan, Jakarta.

Wajahatullah, U.P,Rayirath, S, Subramanian, M.N, Jithesh, P,Rayorath, D.M, Hodges, A.T,Critchley, J.S,Craigie, J, Norrie, and B, Prithiviraj. 2009. Seaweed Extracts as Biostimulant of Plant Growth and Deveploment. J. Plant Growth Regul. 28:386-399.

Williams, D.C., K.R, Brain, G, Blunden, P.B,Wildgoose, and K,Jewers. 1976. Plant Growth Regulatory Substances in Commercial Seaweed Extracts. Proc. Int Seaweed Symp. 8: 59-63.

Wu, T.W. and C.H, Lin. 2000. Analysis of Cytokinin Activity in Commercial Aqueous Seaweed Extract. Gartenbauwissenschaft. 65(4): 170-173.

Yusuf, R., Kristiansen, P., A, Syakur, H, Mas'ud, and Hawalina, 2015.Detecting Plant Grouth Regulator In Seaweeds Using Bioassay. Proceding of The $1^{\text {st }}$ International Conference on Applied Marine Science and Fisheries Technology. Hal. 107-112.

Yusuf, R., P, Kristiansen, and N, Warwick, 2012. Potential Effect of Plant Growth Regulaotor in Two Seaweed Products. Acta Horticulture 958. Hal 133-138. 